B. and Zupancic, A. O. : Arch. Int. Pharmacodyn., $136: 47,1962$. 19) Koelle, G. B.: J. Pharmacol. exp. Therap., $100: 158,1950 ; 103: 153,1951$; J. Comp. Neurol., $100: 211,1954$. 20) Kondo, M.: Okayama J. Med., 71 : 3569, $1959 . \quad 21)$ Mohme-Lundholm, E. : Acta Physiol. Scand., 54 : 200, $1962 . \quad$ 22) Nachlas, M. M., Tsou, K. C., De Sousa, E., Cheng, C. S. and Seligman A. M. : J. Histochem. Cytochem. $5: 420,1957 . \quad 23)$ Nachmias, V.T. and Padykula, H. A.: J. Biophys. Biochem. Cytol., $4: 47,1958 . \quad 24)$ Ogata, T. : Acta Med. Okayama, $12:$ 215, $1958 . \quad 25)$ Okajima, K.: Okayama J. Med., 71 : 4299, 1959. 26) Kure, K. and Okinaka, S.: Autonomic Nervous System, Nippon-isho, Tokyo, 1950. 27) Pearse, A.G.E. : Nature, $191: 504,1961 . \quad$ 28) Saito, K.: Okayama J. Med., $7: 4377$, 1959. 29) Schmid, R., Robbins, P. W. and Traut, R. : Proc. Nat. Acad. Sci., $45: 1236$, 1959. 30) Shy, G., Engel, W. K. and Wanko, J.: Ann. Int. Med., 56 : 511, $1962 . \quad 31$ ) Sibrik, I. De and O'Doherty, D. S. : Neurology, $13: 544,1963 . \quad$ 32) Stein, J. M., Padykula, H. A : Am. J. Anat., $110: 103,1962 . \quad 33)$ Takeuchi, T. : J. Histochem. Cytochem., 3 : 153, $1955: 8: 277,1960 . \quad 34)$ Uono, M., Tanabe, H., Ueda, S. and Tomonaga, M. : Proc. Jap. Histochem. Ass. $2: 2,1961$.

\title{
Histochemical Study on the Auran Metamorphosis Enzyme Activities in the Retracting Tail Tissues*
}

\author{
Mitio Nizzima and Reiji Hirakow \\ Department of Anatomy, School of Medicine, Tokyo Medical \\ and Dental University, Tokyo
}

During metamorphosis striking changes occur in various organs and tissues of amphibia. Over the years many studies have been carried out and several theories were presented to explain the mechanisms of metamorphosis. One of the present authors has studied connective tissue of the skin during metamorphosis (Niizima, 1955) and the behavior of metamorphosing tissues in tissue culture (Niizima, 1956). In our laboratory, electoron microscopic study of amphibian tissues during metamorphosis is also in progress.

Most of the investigations which have been reported up to the present were restricted to histological or experimental studies. Although there have recently been many biochemical studies, the authors have been unable to find any reports of histochemical investigations in this field so far.

Since histochemistry shows the distribution of substances in tissue but cannot accurately determine their exact quantities, it becomes necessary, for the understanding of the phenomena in metamorphosis, to compare biochemical data with histochemical findings.

In the present investigation, attempts were made to determine whether any changes in the localization of activities of some enzymes in the meta-

* More detailed report will be published in Acta Anat. Nippon. 39, 1, 1964 (in Japan.) 
morphosing tail tissue could be detected, in order to clarify which enzymes play an important role in the metamorphosis or involution of the tail.

The tail was chosen as the first object of our studies since the retraction of the frog tail is one of the most conspicious phenomena among the many changes occuring during metamorphosis. The enzymes investigated were alkaline and acid phosphatases, leucine aminopeptidase, succinate dehydrogenase and cytochrome oxidase.

\section{Materials and Methods}

Anuran species used were Rana temporia ornativentris and Rhacophorus schlegelii arborea. The use of these two species was convenient for the long term experiments, because the former metamorphoses early in the summer, while the latter metamorphoses late in the summer or early in the autumn.

Metamorphic stages investigated were from stage XX (i.e. when eruption of the fore limb occurs and the tail shows no visivle signs of retraction) to stage XXIV (when the tail is almost completely absorbed). Staging was done as recommended by Taylor and Kollrs (1946).

For the demonstration of enzymatic activity, most of the histochemical procedures were carried out according to the summarized description in the Pearse's "Histochemistry" (1961), though some procedures were somewhat modified when applied to cold blooded amphibia. Fresh frozen sections (transverse and sagittal) were cut in a cryostat $\left(-20^{\circ} \mathrm{C}\right)$ at about $10 \mu$.

Alkaline and acid phosphatase activities were demonstrated by the azo dye coupling method at $\mathrm{pH} 10$ and 5, respectively. Sodium $\alpha$-naphthyl phosphate was used as substrate and Fast blue B as coupler.

Leucine aminopeptidase activity was demonstrated by the method after Nachlas et al. (1957). The medium contained L-leucyl- $\beta$-naphthylamide and Fast blue B.

The technique for cytochrome oxidase used was that of Burstone (1959). The medium contained $\mathrm{N}$-phenyl-p-phenylenediamine and 1-hydroxy-2-naphthoic acid.

Succinate dehydrogenase activity was demonstrated by the use of nitroBT, as described by Nachlas et al. (1957).

Incubation of the specimens, in most of the procedures mentioned above, was carried out at $37^{\circ} \mathrm{C}$ as well as at room temperature, and for about $30-60$ minutes. For control, sections were incubated in the mixture without substrate or incubated after boiled.

\section{Results and Discussion}

Alkaline phosphatase activity was demonstrated mainly in the wall of blood vessels and in the skin at all stages of metamorphosis. Little alteration in its activity was observed during metamorphosis.

Succinate dehydrogenase and cytochrome oxidase showed similar distribution of their activities. They showed weak activity in the muscle of the 
tail throughout metamorphosis, although their activity was stronger in the leg muscle of the same specimen.

Acid phosphatase altered its activity during metamorphosis. At the beginning of tail retraction (stage XXI), activity of the enzyme was not clearly shown in any of the tail tissuse, but it gradually increased in intensity and became localized in the epidermis, degenerating muscles and involuting notochord. Even at the time when the tail was almost completely absorbed (after stage XXIV), the activity remained at the tip of the body end, that is, the site of the absorbed tail.

Leucine aminopeptidase was another interesting enzyme which performed specific change of activities during metamorphosis. This enzyme was demonstrated first in the sheath of notochord as early as stage XXI, though somewhat faintly. As the retraction of the tail progressed, staining became more intensified in the notochordal sheath and its distribution was spread to other tissues, such as epidermis and degenerated muscles of the tail tip which were undergoing transformation to connective tissues.

As with acid phosphatase, the intensity of the activity of leucine aminopeptidase was greater at the tip of the tail.

Comparison of biochemical data with histochemical findings should be made carefully, since the methods applied in both fields of science are different. At the present stage of study, however, the only way is to compare both results directly. Nevertheless, even in this simple comparison, certain significances of enzyme activities seem to emerge towards the interpretation of auran metamorphosis.

Biochemical data obtained so far by various workers pointed out that, in the metamorphosing tails, alkaline glycerophosphatase and acid glycerophosphatase increased (Yanagisawa, 1953), succinate dehydrogenase decreased (Yamamoto, 1960), alkaline phenylphosphatase decreased and acid phenylphosphatase increased and proteinase increased (reviwed by Urbani, 1962), adenosine triphosphatase decreased and cathepsine, acid phosphatase and acid desoxyribonuclease increased (Weber, 1963). Other enzymes investigated biochemically in various organs of amphibian larvae were also reported, but will not be discussed here as they have no direct bearing on the subject of this report.

It is interesting to note that there is an increase in the activities of lytic enzymes and a decrease in that of the energy producing systems. These biochemical findings has been confirmed by the histochemical findings in the present investigation, although further work will have to be done on the energy producing systems. Weber (1963) indicated that cathepsine, acid phosphatase and acid desoxyribonuclease play an important role in the histolysis of the tail tissues, calling these three enzymes as "katabolische Fermente".

The results of our histochemical observations seem to be consistent with these biochemical suggestions.

\section{References}

1) Burstone, M. S. : J. Histochem. Cytochem. 7, 112-122, 1959.

2) Nachlas, M. M., Crawford, D. T. and Seligman, A. M. : J. Histochem. Cytochem. 5, 264-278, 1957. 
Nachlas, M. M., Tsou, Kwan-Chung, de Souza, E., Cheng, Chao-Shing, and Seligman, A. S. : J. Hisochem. Cytochem. 5, 420-436, $1957 . \quad$ 4) Niizima, M. : Annual Rep. Co-operative Res., Ministry of Education-Medicine-1955. (in Japan.). 5) Niizima, M.: Okajima Folia Anat. Japon., 28, 59-70, 1956. 6) Pearse, A.G.E. : Histochemistry, Churchill Ltd. London, 1961. 7) Urbani, E.: Advances in Morphogenesis, Academic Press, New York, 1962. 8) Weber, R. : Induktion und Morphogenese, Springer-Verlag, Berlin, 1963. 9) Yamamoto, K.: Endocrinol. Japon. 7, 8-12, $1960 . \quad 10)$ Yanagisawa, T. : Repts. Liberal Arts Fac. Shizuoka Univ. Nat. Sci. 4, 20-26, 1953.

\title{
Histochemical Study of Oxidative Enzymes During Wound Healing
}

\author{
Kinzi Yoshikawa, Kazuro ОномасHI \\ and Masahiko MoRI \\ Department of Oral Surgery, Osaka University Dental School, Osaka.
}

\section{Introduction}

Histochemical studies on enzymes during wound healing have been made with some hydrolytic enzymes such as alkaline phosphatase, acid phosphatase, esterase and aminopeptidase. Oxidative enzymes have been reported regarding only succinic dehydrogenase of wound healing's. In the present study, the distribution and intensity of several dehydrogenases participating many metabolic pathway was examined. The oxidative enzymes domonstrated were succinic and malic dehydrogenases from TCA cycle, lactic dehydrogenase from Embden-Meyerhof pathway, glucose-6-phosphate dehydrogenase of pentose cycle, $\alpha$-glycerophosphate dehydrogenase of glycerin fermentation, glutamic dehydrogenase in the amino acid metabolism and $\beta$-hydroxybutyric dehydrogenase of fatty acid cycle. Those enzymes were observed as to the proliferating and maturating stages in both epithelial and mesenchymal tissues during wound healing.

\section{Material and Methods}

Forty adult rats were employed. After shaving off the back skin, an incision and a burn were made at about $1 \mathrm{~cm}$ distance in the back skin of $1.5 \mathrm{~cm}$ in length each reaching down the muscular fascia. The animals were sacrificed 6,12 and 24 hours, 3, 5, 7, 10, 15, 20 and 25 days after injury. The specimens were obtained from the wound regions with the sourrounding normal tissue. These sections were cut at $10-20 \mu$ in a cryostat at $-20^{\circ} \mathrm{C}$ with sliding microtome. Serial cold microtome sections were dried at room temper- 